\title{
Title VII of the Civil Rights Act of 1964 and Minority Group Entry into the Building Trade Unions
}

\begin{abstract}
At a time when the high rate of black unemployment is a leading cause of racial unrest in our nation, ${ }^{1}$ the construction industry is actually experiencing a shortage of skilled labor. ${ }^{2}$ Even with present union members working large amounts of overtime, ${ }^{3}$ demand still far exceeds supply. ${ }^{4}$ As a result, although productivity gains in recent years seem to have been minimal, ${ }^{5}$ wages have increased considerably both in absolute terms ${ }^{6}$ and in comparison with other industries.? Moreover, barring a major economic setback, this demand is not likely to diminish in the future. ${ }^{8}$
\end{abstract}

1 See R. KENNEdy, To SEek a NeWER World 34-35 (1968); National Advisory COMM'N oN CIVIL Disorders, Report 413 (Bantam ed. 1968).

2 Garino, Home Builders Hobbled by Lack of Skilled Help as Well as Tight Money, Wall Street Journal, May 1, 1968, at 1; Jedlicka, Crafts Training Gets Push, Chicago Daily News, Aug. 2, 1968, at 12; Wicker, New Construction in Building Trades, Chicago Today, Oct. 3, 1969, at 25.

3 A May 1967 survey by John Fenlon, an economist for the Bureau of Labor Statistics, showed that $22.9 \%$ of all workers in the construction industry worked more than 41 hours a week. (This survey included union and nonunion, skilled and unskilled workers). Fenlon, Patterns in Overtime Hours and Premium Pay, MONTHLY LABOR REv., October 1969, at 42,45 . Estimates of how much the industry pays in overtime costs run as high as one billion dollars a year. O'Hanlon, The Unchecked Power of the Building Trades, ForTune, Dec. 1968, at 102. See also Jedlicka, supra note 2, at 12.

4 See authorities cited note 2 supra.

5 While the most optimistic union estimates place productivity gains at about $3 \%$, some more conservative estimates have actually shown a slight decline in productivity in recent years. O'Hanlon, supra note 3, at 106. However, it should be noted that these are only estimates, since statistics on productivity in the construction industry are "virtually non-existent." Sabghin, Kaplan, \& Musgrave, Construction Price Stability-An Enigma, Construcrion Rev., Aug. 1969, at 4, 5.

6 The Bureau of Labor Statistics estimates that hourly scales of unionized trade workers rose $70.1 \%$ during the last decade. BNA DAILY LABOR REP., Nov. 10, 1969, at B-1. The average increase for the year ended Oct. 1, 1969, was $8.7 \%$ or 44 cents/hr. Id. at B-1. This rise brought the average hourly wage scales to a record $\$ 5.67 / \mathrm{hr}$. Including employer payments to insurance (health and welfare), pension, and/or vacation funds, the average compensation of unionized trade workers was $\$ 6.35 / \mathrm{hr}$. Id. at 8-1.

7 A year-end analysis by the Bureau of National Affairs, Inc. showed that, while the rise in negotiated median wage settlement gains for all industries in 1969 was 22.1 cents/ $\mathrm{hr}$., the gain in construction last year was 70.2 cents/hr. The next highest wage settlement gains were in shipping and longshoring, 38.0 cents/hr., and printing and publishing, 24.9 cents/hr. BNA DAILY LABOR REP., Jan. 8, 1970, at B-1-B-2. In fact, the survey concluded that much of the sharp acceleration in all industry wage gains is directly attributable to construction settlements. Id. at B-I.

8 Housing Secretary Richard Van Dussen estimates that, if the nation is to meet its 
Any realistic plan designed to use the demand for skilled labor in the building trades as a means of easing black unemployment must effect changes in the policies and practices of the trade unions, since this manpower shortage is largely the artificial creation of those unions. ${ }^{9}$ The unions are able to restrict supply effectively by forcing employers to use the union hiring halls as their single source of labor and by controlling the number of people entering their apprenticeship programs. ${ }^{10}$ Theoretically, the unions should not have this power; under the Labor-Management Relations Act, union membership cannot be made a precondition of employment. ${ }^{11}$ However, the unions achieve the same result without violating the Act by including in their contracts a provision allowing employers to hire outsiders if the union cannot supply the necessary manpower within forty-eight hours of the employer's request. In practice, an employer who signs such a union contract seldom, if ever, hires nonunion men.12 Since the unions have been quite successful in signing these contracts with the major contractors (especially in "contract construction"- - offices, stores, high-rise apartments, and highways), ${ }^{13}$ most of the better jobs in the building trades are subject to union control.

These same unions which exercise great control over this prime source of jobs have historically had a very low percentage of black members. ${ }^{14}$ Even today, after extensive federal pressure ${ }^{15}$ and supposedly active union efforts at compliance, ${ }^{16}$ blacks, who constitute

housing goals for 1975, it would need to add 140,000 skilled workers in the building trades each year. Wicker, supra note 2, at 25.

9 See F. Marshall \& V. Briggs, The Negro and Apprenticeship 13 (1967); P. Norgren \& S. HiLl, Toward Fatr EMPLOYMent 48 (1964).

$10 \mathrm{Id}$.

11 According to the Labor-Mfanagement Relations Act (Taft-Hartley), 29 U.S.C. $\S 158$ (b) (1947):

It shall be an unfair labor practice for a labor organization or its agents . . .

(2) to cause or attempt to cause an employer to discriminate against an employee

in violation of subsection (a)(3) of this section ....

29 U.S.C. $\$ 158(2)(3)$ makes it illegal for employers:

by discrimination in regard to hire or tenure of employment or any term or condition of employment to encourage or discourage membership in any labor organization ....

12 O'Hanlon, supra note 3 , at 105.

$13 \mathrm{Id}$. at 104.

14 F. Marshall \& V. Briggs, supra note 9, at 34-37.

15 For a general history of the federal effort to end job bias see Jenkins, Study of Federal Effort to End Job Bias: A History, A Status Report, and A Prognosis, 14 How. L.J. 259 (1968). For a study dealing specifically with the federal contractor program, see Note, Executive Order 11246: Anti-Discrimination Obligations in Government Contracts, 44 N.Y.U.L. REV. 590 (1969).

16 In 1967 the construction unions, bowing to government, public, and civil rights pressure, supposedly started actively recruiting blacks. Gilbride, Unions Act, But Too Slow to Suit Blacks, Chicago Sun-Times, Sept. 22, 1969, at 5. To aid in these training 
about 12 per cent of the nation's population, still represent only 4 per cent of the building trade apprentices. ${ }^{17}$ While the unions have, with some justification, attributed this racial imbalance to the lack of qualified blacks, there can be little question that union racial prejudice and discrimination have been major reasons for the low percentage of blacks in the building trades. ${ }^{18}$

The pattern of exclusion goes deeper than the national figures would seem to indicate. In the central cities, most of which have experienced major racial disturbances, the disparity between the percentage of blacks in the population and the percentage in the building trade unions is greater than it is in the nation as a whole. ${ }^{19}$ Furthermore, those blacks presently in the unions tend to be concentrated in the

and recruitment efforts, the unions have received nearly $\$ 4$ million in federal funds in the last two years. N.Y. Times, Sept. 22, 1969, at 23.

17 N.Y. Times, Sept. 22, 1969, at 23. It should be pointed out that this $4 \%$ figure represents an improvement over 1967 when blacks accounted for only $2 \%$ of the apprentices.

18 F. MARShall \& V. BRIGGs, supra note 9, at 34.

19 For example, in Chicago where blacks approximate $30 \%$ of the population, they constitute only $3.2 \%$ of the skilled work force, Frailey, Find Few Blacks in Skill Jobs Here, Chicago Sun-Times, Sept. 6, 1969, at 4, and 6.1\% of the apprentices, Frailey, Figures Cited in Wrangle over Union's Apprentices, Chicago Sun-Times, July 27, 1969, at 22. The respective trade union breakdown is:

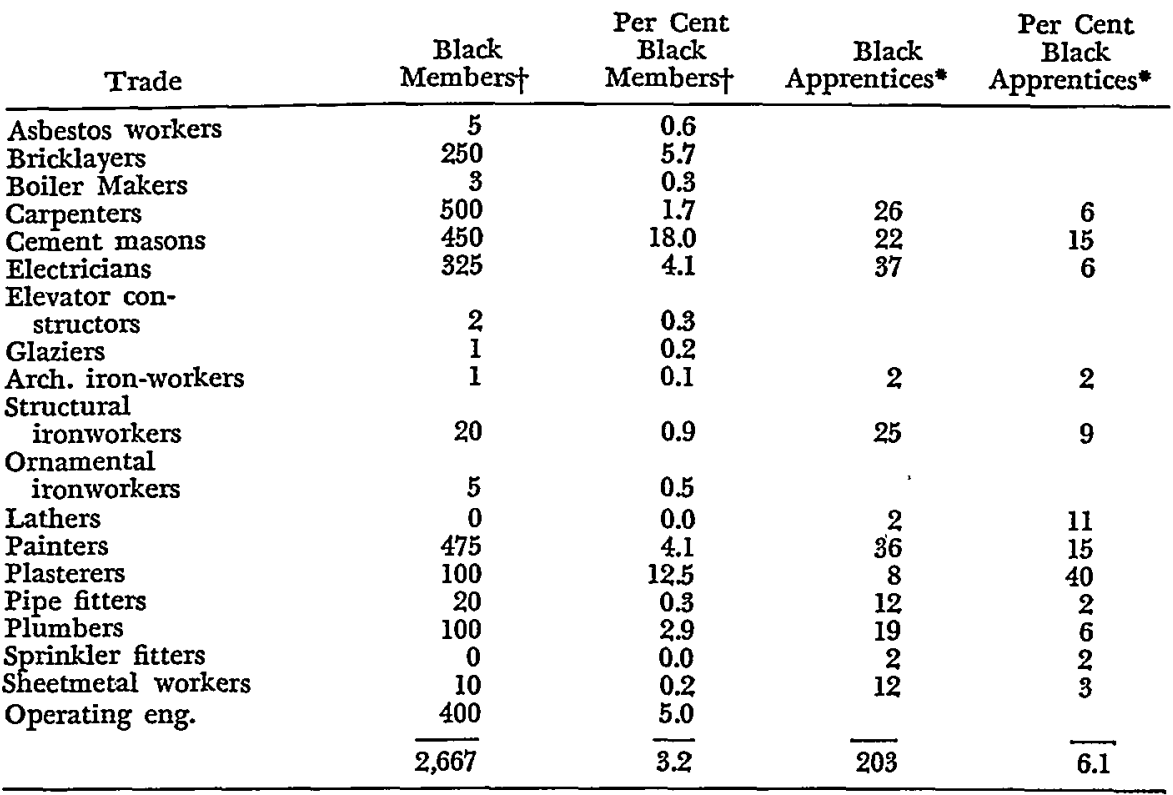

+ based on federal government statistics.

* figures represent black enrollment in union apprenticeship programs at Washburne Trade school (the figures for structural ironworkers include apprentices at Chicago Vocational High School as well as Washburne). 
"mud trades"-bricklaying, plastering, and cement masonry.20 As a result, the percentage of blacks in the more prestigous and better paying unions-electricians, sheet metal workers, plumbers, and pipe-fitters-is frequently less than the already low 4 per cent national average. $^{21}$

Although the more overt forms of union racial discrimination have been removed, substantial barriers to minority group entry still remain. Often union policies and practices which appear to apply to black and white alike actually have a discriminatory impact, upon the former. ${ }^{22}$ The three most serious forms of such covert discrimination are: ${ }^{23}$

(1) Admission Standards. Because of past exclusion and cultural factors, many of the criteria presently used for admission to the union itself and to the apprenticeship program tend to discriminate against members of minority groups.

(2) Recruitment Practices. Passive union recruitment policies usually result in information about openings in the building trades reaching only the close friends or relatives of present union members. Since few union members are members of minority groups, little information about these opportunities reaches the ghetto.

(3) Membership Size. Restrictions on membership size prevent significant numbers of blacks from entering the building trades.

Title VII of the Givil Rights Act of 1964 provides a possible remedy for these more complex forms of discrimination. Under sections $706(\mathrm{~g})^{24}$ and $707(\mathrm{a}),{ }^{25}$ the courts have the power not only to enjoin

20 See charts cited note 19 supra; Equal Employment Opportunity Commission nationwide survey of minority membership, BNA DAILY LABOR REP., Sept. 29, 1969, at A-4-5.

21 See note 20 supra.

22 F. MArshate \& V. Briggs, supra note 9, at 33-45; Strauss \& Ingerman, Public Policy and Discrimination in Apprenticeship, 16 HAsTINGs L.J. 285, 292-8 (1965).

23 See note 20 supra; Interview with John Hall, Director of the Chicago Urban League Apprenticeship Division, in Chicago, Oct. 9, 1969 [hereinafter cited as Urban League Interview].

24 Civil Rights Act of 1964, § 706(g), 42 U.S.C. $\$ 2000 \mathrm{e}-5(\mathrm{~g})$ (1964), provides in relevant part:

If the court finds that the respondent has intentionally engaged in or is intentionally engaging in an unlawful employment practice charged in the complaint, the court may enjoin the respondent from engaging in such unlawful employment practice, and order such affirmative relief as may be appropriate ....

25 Civil Rights Act of 1964, § 707(a), 42 U.S.C. $\$ 2000 \mathrm{e}-6(\mathrm{a})$ (1964), provides:

Whenever the Attorney General has reasonable cause to believe that any person or group of persons is engaged in a pattern or practice of resistance to the full enjoyment of any of the rights secured by this subchapter, and that the pattern or practice is of such a nature and is intended to deny the full exercise of the rights herein described, the Attorney General may bring a civil action .... re- 
union discrimination, ${ }^{26}$ but also to order affirmative relief where appropriate. This comment will explore the scope of this power, both in terms of the general conditions under which relief may be granted and the options open to the courts in shaping such relief. Specifically, this comment will examine the possibility of using Title VII as a means of changing union admission standards, requiring the union to recruit actively among minority groups, and forcing the union to increase the size of its membership.

\section{General Conditions Under Which Relief May Be Granted}

While the public ${ }^{27}$ and private $^{28}$ relief provisions of Title VII differ somewhat in wording, they place essentially the same two conditions on the granting of the type of relief with which this comment is concerned: first, union policy or conduct must be intentional; secondly, it must constitute a pattern or practice of resistance to the rights secured by the Act. ${ }^{29}$ Since the term "pattern or practice" is intended to consist of engaging "repeatedly and regularly ... in acts prohibited by the statute," 30 and since union racial discrimination is an act the statute

questing such relief, including an application for a permanent or temporary injunction, restraining order or other order against the person or persons responsible for such pattern or practice, as he deems necessary to insure the full enjoyment of the rights herein described.

26 Unlawful union employment practices are defined in Civil Rights Act of 1964, § 703, 42 U.S.C. § 2000e-2 (1964):

(c) Labor organization practices.

It shall be an unlawful employment practice for a labor organization-

(1) to exclude or to expel from its membership, or otherwise to discriminate against, any individual because of his race, color, religion, sex, or national origin;

(2) to limit segregate, or classify its membership, or to classify or fail or refuse to refer for employment any individual, in any way which would deprive or tend to deprive any individual of employment opportunities, or would limit such employment opportunities, or otherwise adversely affect his status as an employee or as an applicant for employment, because of such individual's race, color, religion, sex, or national origin; or

(3) to cause or attempt to cause an employer to discriminate against an individual in violation of this section.

(d) Training programs.

It shall be an unlawful employment practice for an employer, labor organization, or joint labor-management committee controlling apprenticeship or other training or retraining, including on-the-job training programs to discriminate against any individual because of his race, color, religion, sex, or national origin in admission to, or employment in, any program established to provide apprenticeship or other training.

27 Givil Rights Act of 1964 § 707(a), 42 U.S.C. § 2000e-6(a) (1964).

28 Civil Rights Act of 1964 \& 706(g), 42 U.S.C. \& 2000e-5(g) (1964).

29 Compare Asbestos Workers, Local 53 v. Vogler, 407 F.2d 1047 (5th Cir. 1969) with United States v. Sheet Metal Workers, Local 36, 416 F.2d 123 (8th Cir. 1969). Compare Dobbins v. IBEW, Local 212, 292 F. Supp. 413 (S.D. Ohio 1968) with United States v. IBEW, Local 38, $59 \mathrm{CCH}$ Lab. Cas. If 9226 (N.D. Ohio 1969). 30110 CoNG. REc. 14270 (1964) (remarks of Senator Humphrey). 
prohibits, ${ }^{31}$ judicial relief may be granted whenever a union is intentionally engaged in acts of discrimination.

\section{A. "Intentionally engaged in"}

According to the majority judicial interpretation, Title VII requires only an intention to engage in the specific employment practices in question, not an intention to use those practices to discriminate. ${ }^{32}$ As long as union actions are not accidental or inadvertent, the discriminatory effects of those actions, not the subjective motives behind them, are controlling. ${ }^{33}$ Some courts do not even bother to discuss the state of mind of the defendant union or employer; only the effects of the allegedly discriminatory acts are considered. ${ }^{34}$

A few decisions have departed from this view by attributing some importance to the defendant's state of mind. In United States v. Local 38,35 the court held that if reasonable, nonracially motivated explanations for the union's conduct or policies exist, the court will not order relief even though these actions have racially discriminatory effects. ${ }^{36}$ Similarly, in Dobbins v. Local $212^{37}$ and United States $v$. H. K. Porter Co.,$^{38}$ the courts cited the good faith efforts of the respective union and employer to end discrimination as a sufficient reason to deny relief. ${ }^{39}$ Alternatively, these three cases may have turned on a finding that the efforts of union or employer had completely eliminated the dis-

31 See note 26 supra.

32 United States v. Hayes Int'l Corp., 415 F.2d 1038 (5th Cir. 1969); Papermakers \& Paperworkers, Local 189 v. United States, 416 F.2d 980 (5th Cir.), cert. denied, 38 U.S.L.W. 3320 (U.S. Feb. 24, 1969) (No. 1015); United States v. Sheet Metal Workers, 416 F.2d 123 (8th Cir. 1969); Clark v. American Marine Corp., 304 F. Supp. 603 (E.D. La. 1969).

33 Papermakers \& Paperworkers, Local 189 v. United States, 416 F.2d 980, 997 (5th Cir. 1969).

34 See, e.g., Asbestos Workers, Local 53 v. Vogler, 407 F.2d 1047 (5th Cir. 1969); United States v. Plumbers \& Pipefitters, Local 73, 61 CCH Lab. Cas. I 9329 (S.D. Ind. 1969); Quarles v. Philip Morris, Inc., 279 F. Supp. 505 (E.D. Va. 1968).

$3559 \mathrm{CCH}$ Lab. Cas. I 9226 (N.D. Ohio 1969).

$36 I d$. at 6935 .

37292 F. Supp. 413 (S.D. Ohio 1968).

38296 F. Supp. 40 (N.D. Ala. 1968).

39 The Dobbins court, referring to the union's affirmative efforts to recruit blacks, concluded that " $[w]$ hatever its shortcomings, if any, in respect of informing the youthful citizenry of its program and the methods of affiliation, those shortcomings have certainly been remedied this year." 292 F. Supp. 413, 440 (S.D. Ohio 1968). The court in the H.K. Porter Co. case refused to change the company's departmental transfer program, because changes in this program in 1965 had afforded blacks opportunities for advancement and higher earnings in the departments to which they were originally assigned. $296 \mathrm{~F}$. Supp. 40, 68 (N.D. Ala. 1968). 
criminatory effects of their admission and recruitment policies. ${ }^{40}$ If, however, discrimination was not completely eliminated in the above cases, and these courts still held that "good faith" efforts to correct the effects of past discrimination negate the intention required under Title VII, then the majority view of the "intention" requirement would have achieved a quite different result.

Under the majority interpretation, attempts at improving employment practices, even "good faith attempts," do not negate a showing of intention to discriminate unless those efforts completely eliminate any discriminatory impact those practices might have. Partial correction is not enough. In United States $v$. Hayes International Corp., ${ }^{41}$ the court invalidated a departmental transfer system which partially eliminated the discriminatory effects of the company's former practice of segregating departments and lines of progression, but did not place blacks on an equal footing with whites in competing for promotions. The court based its decision on the ground that "Title VII of the 1964 Civil Rights Act is not an equal pay provision but an equal opportunity to the full enjoyment of employment rights." 42

The legislative history of Title VII seems to support the majority view of "intention." According to Senator Humphrey, the term "intentionally" was inserted only as a clarifying change in no way meant to limit the scope of the Act:

The express requirement of intent is designed to make it wholly clear that inadvertent or accidental discrimination will not violate the title or result in entry of court orders. ${ }^{43}$

Senator Dirksen also viewed the term "intention" mainly as an excuse for accidental violations. In an earlier amendment to the relief sections of Title VII, he proposed that only willful discrimination be prohibited:

The words "willful" and "willfully" as ordinarily employed, mean nothing more than the person, of whose actions or default the expressions are used, knows what he is doing, intends what he is doing, and is a free agent....

40 The interpretation of intention adopted in Local 38 may also be ascribed to the court's favorable impression of the efforts of the new union leadership to eliminate racial discrimination. According to the court, "[t]he effects of past discrimination have rather effectively been dissipated by the policies of the present union leadership." $59 \mathrm{CCH} \mathrm{Lab}$. Cas. If 9226, at 6929 (N.D. Ohio 1969).

41415 F.2d 1038 (5th Cir. 1969).

42 Id. at 1043; accord, United States v. Plumbers \& Pipefitters, Local 73, 61 CCH Lab. Cas. \9329, at 6865 (S.D. Ind. 1969).

43110 CONG. REc. 12724 (1964). 
The terms are also employed to denote an intentional act $\ldots$ as distinguished from an accidental act ....

This is precisely the situation which might exist if the words are not added .... Accidental, inadvertent, heedless, unintended acts could subject an employer to charges under the present language. ${ }^{44}$

While Dirksen's amendment was defeated at the time, he was the co-author of the bill that ultimately passed Congress and his view of intention was probably reflected in that final version.

This congressional view of the term "intentionally" as a minor clarifying change, not meant to limit the applicability of the Act, is best effectuated by the majority judicial interpretation of the term which would ignore subjective state of mind and excuse only accidental violations of the Act. The minority interpretation, on the other hand, gives the term "intentionally" great importance, severely limiting the applicability of the Act. As stated previously, in many cases, the most substantial barriers to minority group entry into building trade unions are not overt discriminatory acts, but facially neutral admission and recruitment polices which, though applied uniformally, tend to have a discriminatory impact. The minority interpretation would sanction such discriminatory practices if imposed for nondiscriminatory reasons ${ }^{45}$ and would greatly facilitate intentional discrimination since the subjective intent to discriminate would be extremely difficult to prove.48 Not only does this standard give the term "intentionally" much greater importance than Congress intended, but it comes close to requiring that racial discrimination be the sole or main motive of the union or employer before relief could be granted-a position that was expressly rejected by both the Senate ${ }^{47}$ and the House. ${ }^{48}$

\section{B. "Acts of Discrimination"}

In defining what acts are prohibited by the statute, the courts have encountered two major difficulties: (1) determining when the union is under a duty to change facially neutral policies which have an adverse impact on groups excluded in the past; and (2) if a duty is found,

44110 CoNg. REc. 8194 (1964).

45 Whether these more complex barriers to minority group entry into the building trades do constitute violations of Title VII is an independent question that will be discussed below. See text at notes 49-87 infra.

48 See Griggs v. Duke Power Co., 61 CCH Lab. Cas. I 9379, at 6995-28 (4th Cir. 1970) (Sobeloff, J., dissenting).

47110 CoNG. REc. 13837-8 (1964).

48 I10 CONG. REC. 2728 (1964). 
deciding whether the existing policies serve any trade-related purpose which would justify negating that duty.

With respect to the first issue, the courts have found little significance in the causes behind any racially differential impacts that may result from facially neutral employment practices. In many instances the link between the differential impact and union or employer discrimination is clear; present employment practices merely perpetuate the results of prior overt discrimination. ${ }^{49}$ In other cases, however, the differential impact may result from conditions, like unequal educational opportunity, ${ }^{50}$ which are divorced from exclusive union or employer control. The courts have held the differential impacts to be discriminatory in both situations, ${ }^{51}$ making little effort to differentiate between them or to provide separate rationale for each. ${ }^{52}$

While the cause of the differential impact has not been a major issue, much controversy has developed over the extent and nature of the activities the unions are obligated to undertake to correct any differential impact resulting from union policies or practices. In this area, the courts have agreed on some very general propositions. First, they have all agreed that the Civil Rights Act of 1964 is prospective; unions cannot be penalized for pre-Act discrimination..$^{53}$ Second, it is generally agreed that a racial imbalance in membership is not per se discrimination, and, under section 703(j) of the Act, ${ }^{54}$ unions are not

49 See, e.g., Papermakers \& Paperworkers, Local 189 v. United States, 416 F.2d 980, 988-9 (5th Cir. 1969); Asbestos Workers, Local 53 v. Vogler, 407 F.2d 1047, 1055 (5th Cir. 1969); Quarles v. Philip Morris, Inc., 279 F. Supp. 505, 516 (E.D. Va. 1968).

50 United States v. Sheet Metal Workers, Local 36, 416 F.2d 123, 136 (8th Cir. 1969); Dobbins v. IBEW, Local 212, 292 F. Supp. 413, 433-4 (S.D. Ohio 1968).

51 See cases cited notes 49 \& 50 supra.

52 In holding a standardized aptitude test invalid, the Sheet Metal Workers court held that relief was necessary "in light of Local 36's pre-1967 record of excluding Negroes and a post-1967 record of discriminating against them as to membership and related benefits." United States v. Sheet Metal Workers, Local 36, 416 F.2d 123, 136 (8th Cir. 1969). The Dobbins court placed a similar reliance on the union's past discrimination, holding that the court had the power to close off the " 'untraveled roads to the illicit end and not only the worn one." "Dobbins v. IBEW, Local 212, 292 F. Supp. 413, 447 (S.D. Ohio 1968).

53 Papermakers \& Paperworkers, Local 189 v. United States, 416 F.2d 980, 987 (5th Cir. 1969); United States v. IBEW, Local 38, 59 CCH Lab. Cas. I 9226, at 6918 (N.D. Ohio 1969); United States v. H.K. Porter Co., 296 F. Supp. 40, 63 (N.D. Ala. 1968).

54 Civil Rights Act of 1964, § 703(j), 42 U.S.C. \$ 2000e-2(j) (1964), provides:

Nothing contained in this subchapter shall be intexpreted to require any employer, employment agency, labor organization, or joint labor-management committee subject to this subchapter to grant preferential treatment to any individual or to any group because of the race, color, religion, sex, or national origin of such individual or group on account of an imbalance which may exist with respect to the total number or percentage of persons of any race, color, religion, sex, or national origin employed by any employer, referred or classified for employment by any employment agency or labor organization, admitted to mem- 
under a duty to cure racial imbalances by extending preferential treatment to minority groups. Finally, the courts have held that practices which perpetuate the effects of past discrimination are prohibited by the Act. ${ }^{55}$

The problem comes in reconciling the last proposition with the first two. The question of which proposition(s) to emphasize is crucial, because eliminating many of the complex forms of discrimination discussed above may require acts that could be interpreted either as eliminating the present effects of past discrimination or as giving preferential treatment to minority groups. In these situations, the courts which have emphasized Congress' prohibition on requiring preferential treatment, section $703(\mathrm{j}),{ }^{56}$ have taken a narrow view of the appropriateness of granting relief. In those cases where the differential impact of union policies can only be eliminated by measures that could be interpreted as extending preferential treatment to groups excluded in the past, the failure of the union to institute such measures will not constitute a pattern or practice of discrimination. ${ }^{57}$

The courts which have emphasized Congress' desire to end all forms of discrimination have reached a different conclusion. ${ }^{58}$ According to this viewpoint, "the Act casts upon those subject to its provisions not merely the duty to follow racially neutral employment policies in the future but an obligation to correct or revise practices which would

bership or classified by any labor organization, or admitted to, or employed in any apprenticeship or other training program, in comparison with the total number or percentage of persons of such race, color, religion, sex, or national origin in any community, State, section, or other area, or in the available work force in any community, State, section, or other area.

55 See, e.g., Papermakers \& Paperworkers, Local 189 v. United States, 416 F.2d 980, 988-9 (5th Cir. 1969); Asbestos Workers, Local 53 v. Vogler, 407 F.2d 1047, 1055 (5th Cir. 1969); United States v. IBEW, Local 38, 59 CCF Lab. Cas. If 9226, at 6919 (N.D. Ohio 1969); Quarles v. Philip Morris, Inc., 279 F. Supp. 505, 516 (E.D. Va. 1968).

ธ6 See, e.g., United States v. IBEW, Local 38, 59 CCH Lab. Cas. $\$ 9226$ (N.D. Ohio 1969); United States v. H.K. Porter Co., 296 F. Supp. 40 (N.D. Ala. 1968); Dobbins v. IBEW, Local 212, 292 F. Supp. 413 (S.D. Ohio 1968).

57 Green, J., in the Local 38 case typified this viewpoint:

It is this Court's conclusion that while some affirmative relief may be appropriate under the Act, it must be carefully delineated so as to avoid transgressing the boundaries established by [§ 703(j)] . . . 59 CCH Lab. Cas. I 9226, at 6919 (N.D. Ohio 1969).

58 See, e.g., United States v. Hayes Int'l Corp., 415 F.2d 1038 (5th Cir. 1969); Papermakers \& Paperworkers, Local 189 v. United States, 416 F.2d 980 (5th Cir. 1969); Asbestos Workers, Local 53 v. Vogler, 407 F.2d 1047 (5th Cir. 1969); United States v. Sheet Metal Workers, Local 36, 416 F.2d 123 (8th Cir. 1969); Clark v. American Marine Corp., 304 F. Supp. 603 (E.D. La. 1969); United States v. Plumbers \& Pipefitters, Local 73, 61 CCH Lab. Cas. If 9329 (S.D. Ind. 1969); Quarles v. Philip Morris, Inc., 279 F. Supp. 505 (E.D. Va. 1968). 
perpetuate racial discrimination." 59 Thus, any failure to take steps necessary to eliminate practices which perpetuate the present effects of past discrimination, would constitute an illegal discriminatory act.

There would appear to be stronger support for those decisions which emphasize Congress' desire to end discrimination. The section which prohibits the courts from requiring preferential treatment, section $703(j)$, was added to the House-passed bill by the Senate largely to assuage fears that the statute would result in the imposition of racial quotas. ${ }^{60}$ Section $703(j)$ reflects this purpose in stating that Title VII shall not be interpreted to require preferential treatment "on account of an imbalance which may exist with respect to the total number or percentage of persons of any race ... in comparison with the total number or percentage of persons of such race"61 in the geographic area. The provision seems to limit relief only in those cases where there is no evidence of discrimination other than a percentage racial imbalance. It would not restrict relief in cases where discrimination was otherwise established-even though such relief might be construed as some form of preferential treatment.

Moreover, the Givil Rights Act of 1964 grew out of a social climate typified "on the one hand, by a growing impatience by the victims of discrimination with its continuance and, on the other hand, by a growing recognition on the part of all of our people of the incompatibility of such discrimination with our ideals and the principles to which this country is dedicated." 62 In this context, the bill which Congress passed should be viewed as "a sweeping civil rights advance,"63 designed to end a wide range of racially discriminatory practices in voting rights, public accommodations, government-owned facilities, public education, and employment. As one court asserted, referring to Title VII specifically, anyone wishing "to read a forceful prohibition against discrimination ... need look no further than the Civil Rights Act itself."64 In other areas where a strong desire to eliminate racial discrimination is evident, the Supreme Court has said

that the court has not merely the power but the duty to render a decree which will so far as possible eliminate the dis-

59 United States v. Sheet Metal Workers, Local 36, 416 F.2d 123, 127 (8th Cir. 1969).

60 See 110 Conc. Rec. 1518 (Remarks of Rep. Celler); 1600 (Rep. Minish); 2558 (Rep. Goodell); 5808 (Sen. Keating); 6563 (Sen. Kuchel); 7207 (Sen. Clark); 7213 (interpretative memorandum jointly submitted by Senators Clark and Case); 12723 (Sen. Humphrey) (1964.) 6142 U.S.C. $\& 2000 \mathrm{e}-2(\mathrm{j})(1964)$.

62 H.R. REp. No. 914, 88th Cong., 1st Sess. (1963); Equal EMrp. OpPortunity CoMm?N, Legislative History of Timles VII AND XI OF THE Givil RIGHTS ACT of 1964, at 2018.

63 United States v. Jefferson County, 372 F.2d 837, 849 (5th Cir. 1966).

64 Asbẹsţ̧os Workęrs, Lọcąl 53 v. Vogler, 407 F.2d 1047, 1051 (5th Cir. 1969). 
criminatory effects of the past as well as bar like discrimination in the future. ${ }^{65}$

The strong thrust of Title VII toward ending racial discrimination in employment, when considered in light of the circumstances surrounding the passage of section $703(\mathrm{j})$, justifies a restrictive reading of this section. The union should be held responsible for the racially differential impact of any of its admission and recruitment policies. As suggested at the beginning of this section, this duty to eliminate the differential impact of union policies may be negated if those policies are sufficiently related to the performance of the job involved. For example, a requirement that all typists be able to type would not be illegal even if it excluded a greater percentage of blacks than whites. The problem arises in determining under what conditions a traderelated purpose will be sufficient to justify a policy or practice which has a differential impact.

In making this determination, the courts have had to strike a balance between conflicting policy considerations. On the one hand, the unions have a definite interest in maintaining and improving the quality of the union work force. Union craftsmen can retain their high wages only if they have lower unit costs than the alternatives available to the employer. If the union accepts many unqualified or incompetent workers, the employer has a strong incentive to mechanize, become nonunion, or look elsewhere for workers. ${ }^{66}$ These considerations would favor allowing the union to employ all policies or practices which have any trade-related value.

On the other hand, most union policies which have a differential impact, even nepotism, ${ }^{67}$ serve some trade-related function. Allowing the unions to employ all policies and practices which have some traderelated value would almost render the Act nugatory as a means of dealing with the more complex forms of trade-union discrimination.

In balancing these considerations, two different views have developed. Some courts have given great weight to the need to maintain the quality of the union work force, holding that as long as the policy or practice involved was related to some "reasonable" or "legitimate" economic purpose, it cannot be prohibited under Title VII. ${ }^{68}$ Although

65 Louisiana v. United States, 380 U.S. 145, 154 (1965) (invalidating interpretation and citizenship tests for voting); accord, Gaston County v. United States, 395 U.S. 285 (1969) (invalidating literacy test for voting).

BB F. MARshaLl \& V. Briggs, supra note 9 , at 13.

67 See Papermakers \& Paperworkers, Local 189 v. United States, 416 F.2d 980, 989 (5th Cir. 1969).

68 Griggs v. Duke Power Co., 61 CCH Lab. Cas. I 9379, at 6695-23 n.8 (4th Cir. 1970); United States v. IBEW, Local 38, 59 CCH Lab. Cas. If 9226, at 6935 (N.D. Ohio 1969); 
these courts are not clear on what is "reasonable" or "legitimate," they seem to require something less than absolute business necessity. ${ }^{69}$ Thus one court upheld a racially differential general aptitude test because it produced some, although not essential, benefit for the employer who instituted it. ${ }^{70}$

Other courts"1 have rejected this "legitimate" or "reasonable" purpose test, holding that any discriminatory impact constitutes irreparable damage.72 One court, for example, has asserted that "when an employer or union has discriminated in the past and when its present policies renew or exaggerate discriminatory effects, its present policies must yield, unless there is an overriding legitimate, non-racial business purpose."73 In short, any union duty to change racially differential policies or practices is only negated if those policies or practices are essential to the performance of the job involved.

On the whole, the business necessity approach strikes the better balance between the above mentioned policy considerations. In view of the congressional policy underlying Title VII, ${ }^{74}$ any exemptions for racially discriminatory practices because of relation to the performance

United States v. H.K. Porter Co., 296 F. Supp. 40, 68 (N.D. Ala. 1968); Dobbins v. IBEW, Local 212, 292 F. Supp. 413, 443 (S.D. Ohio 1968).

69 In fact, the courts have been quite confused on this point. While the Local 38 and Griggs courts talk of "other reasonable alternative explanations," 59 CCH Lab. Cas. I 9226, at 6935 (N.D. Ohio 1969), and "genuine business purpose," 61 CCH Lab. Cas. If 9379, at 6695-23 n.8 (4th Cir. 1970), respectively, the H.K. Porter Co. court only excludes employment policies or practices from the purview of Title VII when a reasonable business purpose is accompanied by substantial opportunities for vertical and horizontal mobility under the present employment policies. 296 F. Supp. 40, 68 (N.D. Ala. 1968). The Dobbins case epitomizes this confusion. At one point, the court seems to be urging a standard of absolute business necessity:

The fair test of an individual's qualifications to work in the electrician trade

in this geographical area is actual ability to work on the job in the trade for the average contractor operating in the trade. 292 F. Supp. 413, 434 (S.D. Ohio 1968).

Yet, at other times, the court reverts to a standard which includes a nebulous view of reasonableness plus a subjective interpretation of intention. Referring to pre-Act employment practices, the court states:

$[\mathrm{I}] \mathrm{f}$ it was adopted originally for a purpose having nothing to do with discrimination and for a legitimate economic purpose-the continuance could not be "per se" discriminatory. $I d$. at 443.

70 Griggs v. Duke Power Co., 61 CCH Lab. Cas. If 9379, at 6695-23 (4th Cir. 1970). The economic benefit in this case was that the tests would supposedly improve the overall quality of the work force.

71 See cases cited note 58 supra.

72 As stated in United States v. Hayes Int'l Corp., 415 F.2d 1038, 1045 (5th Cir. 1969):

Whenever a qualified Negro employee is discriminatorily denied a chance to fill

a position for which he is qualified and has the seniority to obtain, he suffers

irreparable injury and so does the labor force of the country as a whole.

73 Papermakers \& Paperworkers, Local 189 v. United States, 416 F.2d 980, 989 (5th Cir. 1969).

74 See text at notes 6 \& 7 supra and statutes cited note 26 supra. 
of the job involved should be narrowly limited to "bona fide occupational qualifications,"75 like "the preference of a French restaurant for a French cook, the preference of a professional baseball team for male players, and the preference of a business which seeks the patronage of particular religious groups for a salesman of that religion."76 While keeping to a minimum the number of racially differential policies or practices which are excluded from the purview of the Act, the business necessity approach still provides adequate safeguards for union membership quality. Under the business necessity approach, the union does not have to accept incompetent or unqualified applicants for membership; it merely has to judge all applicants according to the skills that are essential to the average journeyman. Whatever extra modicum of union protection may be provided by the legitimate or reasonable purpose test, it is purchased at the price of further restricting the number of discriminatory practices which the Act prohibits-a price that seems exorbitant in view of the apparent congressional intent.

The major obstacle to applying the essential business purpose test to all employment practices comes in applying the principle to standardized aptitude tests. According to section $703(\mathrm{~h}){ }^{77}$ it is not an unlawful employment practice "for an employer to give and act upon the results of any professionally developed ability test provided that such test, its administration or action upon the results is not designed, intended or used to discriminate because of race, color, religion, sex or national origin." Controversy has arisen over whether the strict business necessity approach should be applied to standardized tests in view of this section.

The main argument for not applying the business necessity approach to standardized aptitude test relies heavily on the legislative history of section $703(\mathrm{~h}) .{ }^{78}$ Proponents of this position claim that Congress adopted section 703(h) primarily to insure that Title VII would not be interpreted as the Illinois Fair Employment Practices Act had been in the case of Myart $v$. Motorola which held that a preemployment general intelligence test which Motorola gave to prospective employees illegally discriminated against blacks because blacks were a culturally deprived or disadvantaged group. ${ }^{79}$ Since both proponents and oppo-

75110 CoNG. REc. 7213 (1964) (interpretive memorandum jointly submitted by Senators Clark and Case).

78 Id.

7742 U.S.C. \& 2000e-2(h) (1964).

78 For a good summary of the argument against applying the business necessity test to standardized aptitude tests, see Griggs v. Duke Power Co., 61 CCH Lab. Cas. I 9379, at 6995-22-3 (4th Cir. 1970).

79 The hearing examiner's report in Myart v. Motorola is reprinted at 110 Cong. REc. 
nents agreed that general intelligence and ability tests, if fairly administered and acted upon, were not invalidated by the Civil Rights Act of 1964,80 it could be argued that the business necessity approach should not be applied to these tests. As one court held, the tests should be valid under Title VII as long as they served a "genuine" business purpose and were not designed or used to further racial discrimination. ${ }^{81}$

The reasons for applying the business necessity approach to standardized aptitude tests have been discussed in detail elsewhere. ${ }^{82}$ Briefly, the argument is that section $703(\mathrm{~h})$ was only a clarifying change meant to avoid the per se prohibition of these tests as occurred in the Motorola case; the section was not intended to allow employers or unions to use tests unrelated to job performance. ${ }^{83}$ In view of the Act's strong policy of eliminating barriers to equal employment opportunity, section 703(h) should not be viewed as giving employers and unions wide latitude in the use of an employment practice which has such a markedly adverse effect on blacks. ${ }^{84}$ The only tests which should be immunized under section 703(h) are validated aptitude tests-tests validated by experts and directly related to the aptitudes necessary to perform a particular job.

While the argument for applying the business necessity approach to general aptitude tests has been rejected by one court, ${ }^{85}$ it has been

5662-4 (1964). The case was later reversed on appeal. Motorola v. F.E.P.C., 34 Ill.2d 266, 215 N.E.2d 286 (1966).

80 See, e.g., Griggs v. Duke Power Co., 61 CCH Lab. Cas. I 9379, at 6995-23 (4th Cir. 1970).

81 Griggs v. Duke Power Co., 61 CCH Lab. Cas. I 9379, at 6995-23 n.8 (4th Cir. 1970).

82 See Cooper \& Sobol, Seniority and Testing Under Fair Employment Laws: A General Approach to Objective Criteria of Hiring and Promotion, 82 HARv. L. REv. 1598, 1637-55 (1969); Griggs v. Duke Power Co., 61 CCH Lab. Cas. If 9379, at 6995-25, 6995-26-30 (4th Gir. 1970) (Sobeloff, J., dissenting).

83 In support of this point, proponents of the business necessity approach argue that the original version of $\S 703(\mathrm{~h})$, which its author, Senator Tower, proposed to the Senate, provided that general aptitude tests would only be permissible if "in the case of any individual who is an employee of such employer, such test is designed to determine or predict whether such individual is suitable or trainable with respect to his employment in the particular business or enterprise involved." 110 CoNG. REc. 13492 (1964). According to proponents of the business necessity approach, the present form of $\S 703(\mathrm{~h})$ cannot be viewed as imposing greater restrictions on the applicability of the Act than would have been imposed by Senator Tower's original amendment.

84 In one application of several well-known standardized tests in the South, 58\% of the whites but only $6 \%$ of the blacks obtained passing scores. See EEOC Decision, Dec. 2, 1966, cited in CGH EMPLOYMENT PRACTICEs Guide I 1209.25. The tests involved were the Otis Employment Test and the Wonderlic Personnel Test (both "general intelligence" tests), the Bennett Test of Mechanical Comprehension (a test of physical principles), and the Personnel Test for Industry (PTI) Numerical Test (a test of arithmetic skills).

85 Griggs v. Duke Power Co., 61 CCH Lab. Cas. I 9379, at 6995-23 (4th Cir. 1970). 
accepted in fact by two others ${ }^{86}$ and in principle by two more. ${ }^{87}$ Furthermore, the Equal Employment Opportunity Commission's guidelines on employment testing not only advocate that tests be validated, but also suggest that sample population norms used in validating tests should include representative members of minority groups. ${ }^{88}$ In short, employment practices which have an adverse impact on groups excluded in the past constitute a pattern or practice of discrimination and should justify judicial relief when the existing practices are not essential to the performance of the job involved.

\section{Options Open to the Courts in Shaping Relief}

This section will apply the doctrine developed in the preceding section to union admission standards, recruitment policies, and membership size in order to determine whether the courts should take action and, if such action should be taken, what form this action should take.

\section{A. Admission Standards}

Entry into the building trade unions is usually achieved either by completing the union's apprenticeship program or by fulfilling the requirements for direct admission. ${ }^{89} \mathrm{~A}$ complete discussion of admission standards for either of these two routes to membership is not possible here because standards vary substantially among locals as well as from trade to trade. ${ }^{90}$ The following discussion, therefore, will concentrate on the most common standards, especially the ones that have been subject to litigation under Title VII.

1. Direct Admisssion. An applicant for direct admission to the union must fulfill some or all of the following requirements: ${ }^{91}$ he must be over or under a certain age, be related to a present union member, have a specified number of years experience in the trade (usually 3-5 years), have worked under the the union's collective bargaining agreement for some period of time (usually a year), pass a journeyman's exam, have letters of recommendation from present union members, and be approved by a vote of the union membership.

86 United States v. Sheet Metal Workers, Local 36, 416 F.2d 123, 136 (8th Cir. 1969); Dobbins v. IBEW, Local 212, 292 F. Supp. 413, 433-4 (S.D. Ohio 1968).

87 Papermakers \& Paperworkers, Local 189 v. United States, 416 F.2d 980, 994 (5th Cir. 1969); United States v. H.K. Porter Co., 296 F. Supp. 40, 75-76 (N.D. Ala. 1968).

88 CCH EMPLOYMENT PRACTICES GUIDE, I 1209, at 610.

89 Strauss, Apprenticeship: An Evaluation of the Need, in EMPLOXMENT POLICX AND THE LABOR MARKET 317 (A. Ross ed. 1965).

$90 \mathrm{Id}$. at 318-9.

91 Compiled from cases cited notes 56 \& 58 supra, Strauss, supra note 89, at 319 , and Urban League Interview, supra note 23. 
In terms of differential impact and nonessential trade-related purpose, many of the above criteria for membership admission seem discriminatory. Requiring family relationship to a present union member has already been invalidated, ${ }^{92}$ because it has little, if any, trade-related value and will be likely to bar permanently from union membership groups excluded in the past. The same reasoning would also necessitate the total elimination of maximum age requirements. ${ }^{93}$ When unions have excluded blacks in the past, an upper-age limit on those eligible to apply for direct admission permanently bars from membership blacks who never had a chance to join the union before and are presently above that limit. Since the average age of trade union members seems quite high, ${ }^{94}$ the adverse impact of such an age requirement cannot be justified by business necessity. While the union may have an interest in admitting only relatively young applicants who are perhaps more adept than older applicants, who would be involved in union affairs for a longer period of time, and who would not be as large an immediate drain on union medical or pension funds, this union interest does not constitute a business necessity and must yield before the discriminatory impact inherent in maximum age requirements.

The requirements of experience under the referral system and experience in the trade, while more trade-related than the age or nepotism standards, do not constitute absolute business necessities. What is essential to the performance of a journeyman's trade is the ability to do the job as well as the average journeyman in the area. ${ }^{95}$ While work experience in the trade is undoubtedly helpful in acquiring these skills, it is not the only avenue available. ${ }^{96}$ Furthermore, even where these skills are gained through work experience, it does not necessarily take four years, a typical union requirement, to reach the level of ability possessed by an average journeyman. ${ }^{97}$ If work experience require-

92 Asbestos Workers, Local 53 v. Vogler, 407 F.2d 1047, 1053 (5th Cir. 1969); see United States v. Plumbers \& Pipefitters, Local 73, 61 CCH Lab. Cas. I 9329, at 6865 (S.D. Ind. 1969).

93 The courts have not yet directly confronted this problem although the union in the Vogler case had such a requirement. 407 F.2d 1047, 1049 (5th Cir. 1969).

94 See O'Hanlon, supra note 3, at 106. For example, the average age of members of the carpenter union is 45.6 years and 140,000 of the 800,000 members are over 60 . Id.

95 United States v. Sheet Metal Workers, Local 36, 416 F.2d 123, 136 (8th Cir. 1969); Dobbins v. IBEW, Local 212, 292 F. Supp. 413, 434 (S.D. Ohio 1968).

96 The main, nonunion channels for experience are: (1) completion of part of formal apprenticeship; (2) informal apprenticeship; (3) learning the trade in a nonunion sector of the industry or a related industry; (4) vocational schools; and (5) working one's way up from unskilled or labor classification through a step-by-step process of "stealing" the trade. Strauss, supra note 89 , at 321 .

97 Testimony at hearings conducted by Arthur Fletcher, assistant Secretary of Labor, 
ments do have a discriminatory impact, it is not justified by an overriding trade-related value.

Under most circumstances, both requirements have a definite differential impact. Even where nonunion channels provide blacks with some experience in the trade, ${ }^{98}$ past discrimination in the operation of union-controlled projects will have deprived blacks of the same opportunity whites have had either to work under the referral system or to gain experience in the trade. Therefore, both work experience requirements would place blacks at a disadvantage vis-à-vis whites who had been given that opportunity.99 However, relief in these cases is more likely to involve temporary suspension than outright elimination, because the discriminatory impact of such practices is not permanent. ${ }^{100}$ Four years (or however long the work experience requirement extends) after union discrimination stops and blacks are given an equal opportunity to work in the building trades, the requirement of work experience either in the trade or under the collective bargaining agreement will apply equally to blacks and whites.

With respect to union membership votes and member sponsorship as admission requirements, judicial response has ranged from complete elimination ${ }^{101}$ to suspension ${ }^{102}$ to inaction. ${ }^{103}$ Of the three, elimination seems preferable. Judicial inaction seems inappropriate, because of the difficulties of proving actual discrimination and the possibilities for mischief inherent in membership votes and sponsorship require-

investigating charges of trade union discrimination in Philadelphia. BNA DAILY LABOR REP., Sept. 23, 1969, at F-2 n.2. This fact was impliedly recognized by the unions themselves in the tentative oral agreement reached between the unions and the black coalition in Chicago. This agreement provided for an accelerated training program for blacks which would not last as long as the traditional period for training. Chicago Sun-Times, Nov. 6, 1969, at 3 .

98 Blacks specifically have had opportunities to learn certain trades, like carpentry, within their own communities, working on home building and rehabilitation projects which, until the recent advent of the Model Cities program, were too unprofitable to merit union attention. Urban League Interview, supra note 23.

99 Asbestos Workers, Local 53 v. Vogler, 407 F.2d 1047, 1055 (5th Cir. 1969); Dobbins v. IBEW, Local 212, 292 F. Supp. 413, 446 (S.D. Ohio 1968). But see United States v. IBEW, Local 38, 59 CCH Lab. Cas. If 9226, at 6929 (N.D. Ohio 1969). The Local 38 court, using reasoning criticized earlier (see text at notes $35-48$ supra), felt that healthy economic conditions of the construction industry and the availability of good jobs alleviated the discriminatory impact of the referral system sufficiently to make affirmative relief unnecessary. Id.

100 See, e.g., United States v. Plumbers \& Pipefitters, Local 73, 61 CCH Lab. Cas. I 9329, at 6867 (S.D. Ind. 1969) (requirement of experience under referral system suspended for two years).

101 Asbestos Workers, Local 53 v. Vogler, 407 F.2d 1047, 1053 (5th Cir. 1969).

102 United States v. Plumbers \& Pipefitters, Local 73, 61 CCH Lab. Cas. If 9329, at 6866 (S.D. Ind. 1969).

103 United States v. Sheet Metal Workers, Local 36, 416 F.2d 123, 135 (8th Cir. 1969). 
ments. ${ }^{104}$ Even where it cannot be shown that these two admission requirements are specifically used to discriminate, leaving such discretionary power in the hands of a union which is otherwise engaged in a pattern or practice of discrimination places too much reliance on the good faith of a union which is already discriminating.

Suspension does not solve these problems. Once all forms of discrimination end and the union becomes more racially mixed, members might vote for and sponsor blacks who were otherwise qualified.105 However, there is no guarantee that white union members will act any differently when they constitute only a majority, rather than the entirety, of the membership. Unless the court retains continuing jurisdiction, the possibility of union abuse of this discretionary power would still exist after the suspension ended. To avoid these problems of judicial administration and to guard against the opportunities for discrimination inherent in membership votes and sponsorship requirements, complete elimination of these non-trade-related admission criteria seems desirable whenever the union is or has been otherwise engaged in a pattern or practice of discrimination.

The courts have also been concerned with limiting the discretionary power of unions over the last requirement for direct admission, the journeyman's exam. In order to minimize discrimination and assure actual business necessity, it has been held essential that these tests "be objective in nature, that they be designed to test the ability of the applicant to do that work usually required of a journeyman and that they be given and graded in such a manner as to permit review."108 When the unions have not already adopted such objective, abilityrelated tests, the courts have the power to order them to do so. ${ }^{107}$

Under Title VII, an objective, skill-related journeyman's exam is the only admission standard for union membership that should be permitted where a pattern or practice of discrimination exists. Only after the present effects of past union discrimination in the referral system are completely eliminated should the unions be able to reinstate the work experience requirements. ${ }^{108}$

104 Refusal to sponsor or vote for black applicants is still an important means of informal discrimination in construction unions. P. NORGREN \& S. HrrL, supra note 9, at 46.

105 This seems to be the justification for the Sheet Metal Workers result. 416 F.2d 123, 135 (8th Cir. 1969).

108 United States v. Sheet Metal Workers, Local 36, 416 F.2d 123, 136 (8th Cir. 1969); accord, Dobbins v. IBEW, Local 212, 292 F. Supp. 413, 434, 437 (S.D. Ohio 1968).

107 See note 106 supra.

108 In a particularly blatant case the court could turn the entire admission process over to a "trustee" or disinterested third party appointed by the court. Such drastic measures should not be necessary, since union racial bias should be effectively controlled by limiting the criteria for direct admission to a skill-related journeyman's exam. 
2. The Apprenticeship Program. Unions ${ }^{109}$ examine some or all of the following attributes of applicants for their apprenticeship programs: ${ }^{110}$ age, physical ability, educational background, past work experience, aptitude, and personality. Each of these is usually given a different weight or importance in determining the eligibility of the applicants. ${ }^{111}$ The applicants with the highest scores are then given first preference for openings in the apprenticeship program.

Like membership admission requirements, several of the above criteria for apprenticeship eligibility appear appropriate subjects for judicial relief. Age requirements that limit applicants to a restricted age bracket, e.g., 17-23 years, would permanently bar members of groups excluded in the past who were now over the prescribed age. The courts have dealt with this situation by changing the union referral system in order to make it easier for members of minority groups who are over the age for apprenticeship to gain work experience and, thereby, qualify for direct admission to the union. ${ }^{112}$ This indirect approach seems preferable to raising or eliminating age limits for apprentices, since it achieves the same result as the more direct approach without disturbing the union interest in maintaining a relatively young apprenticeship class.

The courts have also failed to disturb educational background examinations, ${ }^{113}$ although in most cases no cogent rationale exists for maintaining them. Evaluating applicants, as many unions do, by overall high school grades and performance in certain specific courses, like algebra, trigonometry, and physics, is almost certain to exclude more

109 In theory, most apprenticeship programs are run by a joint apprenticeship committee (JAC) composed of equal numbers of union and management personnel. Often, the unions exercise dominant control. Strauss \& Ingerman, supra note 22, at 296.

110 Compiled from cases cited notes 56 \& 58 supra, F. Marshall \& V. Briggs, supra note 9 , at 23, and the registration files of the Illinois State Office of the Bureau of Apprenticeship and Training.

111 In the Dobbins, 292 F. Supp. 413, 437-8 (S.D. Ohio 1968), Sheet Metal Workers, 416 F.2d 123, 137-8 (8th Cir. 1969), and Local 73, $61 \mathrm{CCH}$ Lab. Cas. \ 9329, at 6865 (S.D. Ind. 1969), cases, final scores were a composite of the numerical scores achieved in each area tested. In Local 38, scores in various areas were used only to determine whether the applicant was eligible to take the oral interview. Final ranking was determined solely by the score received on the oral interview. 59 CCH Lab. Cas. I 9226, at 6936-7 (N.D. Ohio 1969).

112 See, e.g., Asbestos Workers, Local 53 v. Vogler, 407 F.2d 1047, 1055 (5th Cir. 1969); United States v. Sheet Metal Workers, Local 36, 416 F.2d 123, 132-4 (8th Cir. 1969); Dobbins v. IBEW, Local 212, 292 F. Supp. 413, 445 (S.D. Ohio 1968).

113 In Dobbins, the union awarded 28 out of 100 points on educational background: 10 for class rank and 18 for specific subjects like algebra. 292 F. Supp. 413, 438 (S.D. Ohio 1968). While not directly addressing itself to this evaluation, the court in discussing the over-all pattern of evaluation stated:

These standards selection-wise and otherwise are not arbitrary, are reasonably related to the Congressional intent of ... Title VII, and they are in no way discriminatory. 
blacks than whites because of the general lack of equal educational opportunity in black communities. ${ }^{114}$ Since class rank, a high school diploma, or knowledge of specific subjects like algebra and trigonometry seems to be indicative of the actual skills needed only in a few trades, ${ }^{115}$ evaluation of these educational criteria should be eliminated except in those trades where knowledge of specific subjects is necessary for performance of the job involved.

The physical ability requirement, on the other hand, seems to be nondiscriminatory. Often no discrimination is even possible because the union itself does not attach much importance to it, requiring only that the applicant be in normal physical health. Where physical ability is used as an important determinant of eligibility for apprenticeship, the abilities tested must be necessary for the performance of the job involved if there is any evidence that the particular standard does have a differential impact.

Past work experience, while possibly a valuable aid to a potential apprentice, would not seem essential to successful completion of the apprenticeship program because one of the purposes of the program is to give apprentices that very experience. In those trades where past exclusion has deprived minority group members of an equal opportunity of gaining work experience, using prior work experience to evaluate applicants would have a discriminatory impact and should be suspended. ${ }^{116}$

The greatest controversy over admission criteria has revolved around the written and oral tests given to applicants. The dispute over written testing has been discussed elsewhere. ${ }^{117}$ Briefly restated, written tests have to be objective, free of personal discretion in grading, and subject to review; they must not be unnecessarily difficult and should be directly related to the abilities necessary for the average journeyman to perform his trade. ${ }^{118}$

114 According to the Kerner Commission:

The bleak record of public education for ghetto children is growing worse. In the critical skills-verbal and reading ability-Negro students fall further behind whites with each year of school completed.

The result is that many more Negro than white students drop out of school. In the Metropolitan North and West, Negro students are more than three times as likely as white students to drop out of school by age 16-17.

National Advisory Comm'n on Civil Disorders, Report 425 (Bantam ed. 1968); accord, F. MARSHALl \& V. BRIGGs, supra note 9 , at 42 . In the nation as a whole in 1968, non-whites, who comprised about $13 \%$ of the nation's population, comprised over $26 \%$ of the high school dropouts. U.S. Dept. of Commerce, Statistical ABstract of the United States 18, 110 (1969).

115 Trme, Sept. 26, 1969, at 88; Urban League Interview, supra note 23. The sheet metal union is a possible exception.

116 See text at notes 99-101 supra.

117 Text at notes 77-88 supra.

118 Authorities cited note 107 supra. 
With respect to the oral interview, the courts have agreed that the tests should be as objective as possible, with the examiner having little personal discretion and the results being subject to review. To this end, unions have been ordered to design their oral interviews so that they clearly delineate the categories to be tested and the points to be awarded within each category. ${ }^{119}$ Unions have also been urged to take steps to insure uniformity in test interpretation..$^{120}$

The major controversy over the oral interview has concerned the weight it is to be given in the final evaluation of the applicant's potential. While none of the courts has suggested complete elimination, they have differed greatly on the weight to be given the tests. The Local 38 court not only rejected a government proposal to limit the oral interview to 10 per cent of the applicant's final point total, but also allowed the union to use the interview as its only basis for differentiating among applicants. ${ }^{121}$ On the other hand, the Local 73 court limited the value of the oral interview to 15 per cent of the total point count an applicant could receive. ${ }^{122}$

In view of the inherent subjectivity of even the most controlled oral interview and the consequent opportunities for covert discrimination, the failure of the courts to eliminate these tests seems unwarranted. As in the case of membership votes and sponsorship requirements, great discretionary power should not be left in the hands of unions which have already engaged in a pattern or practice of discrimination. Since the oral interview does not seem to measure any essential traderelated skills which cannot be measured by written or physical tests, ${ }^{123}$ the possibilities for perpetuating discrimination inherent in the oral interview would appear to justify its complete elimination.

While the courts have thus examined most of the criteria for admission into the apprenticeship program, they have yet to consider the validity of the apprenticeship program itself. Increasing evidence points to the conclusion that some apprenticeship training programs as presently constituted do not serve an overriding trade-related pur-

119 See, e.g., United States v. Plumbers \& Pipefitters, Local 73, 61 CCH Lab. Cas. ๆ 9329, at 6867 (S.D. Ind. 1969). See also United States v. IBEW, Local 38, 59 CCH Lab. Cas. I 9226, at 6938 (N.D. Ohio 1969), where the court only felt it had the power to suggest such changes.

12059 CCH Lab. Cas. I 9226.

121 Id. at 6939.

122 United States v. Plumbers \& Pipefitters, Local 73, $61 \mathrm{CCH}$ Lab. Cas. I 9329, at 6867 (S.D. Ind. 1969).

123 The oral interview is commonly used to measure a number of factors like interest, appearance, ambition, physical potential, personality, and attitude. See, e.g., Dobbins v. IBEW, Local 212, 292 F. Supp. 413, 438 (S.D. Ohio 1968); United States v. IBEW, Local 38, 59 CCH Lab. Cas. If 9226, at 6936 (N.D. Ohio 1969). 
pose. ${ }^{124}$ First, the apprenticeship program is too long; it does not take four years to acquire most, and perhaps all, of the skills of the average journeyman. ${ }^{125}$ Secondly, the apprenticeship program does not meet the current demand for labor in the crafts, much less fulfill demands for an increased labor supply; ${ }^{126}$ consequently a small percentage of present union members actually have gone through full apprenticeship training. ${ }^{127}$ Because apprenticeship, as presently constituted, is arguably not essential to job performance, such programs might be illegal under Title VII if they have a discriminatory impact by discouraging more blacks than whites from entering the building trades.

Unfortunately, no detailed studies have been made on the effect of these programs on either the blacks who actually enter the program or those who may be discouraged from applying because of various facets of apprenticeship. However, according to the director of the apprenticeship division of the Chicago Urban League, which has placed close to 500 blacks in apprenticeship programs, the major problem with apprenticeship is getting blacks into the program, not keeping them there. ${ }^{128}$ Certainly apprenticeship does not represent a heavy financial sacrifice for the potential applicant. Although first year apprentices may receive only half as much pay as journeymen, that salary still amounts to $\$ 2.75 / \mathrm{hr}$. to $\$ 3.00 / \mathrm{hr}$. and each year those wages increase. ${ }^{129}$

Of course, if later data show that the nature of the apprenticeship program either discourages blacks from joining or finishing, then this discriminatory impact coupled with a lack of an overwhelming traderelated purpose could subject apprenticeship itself to judicial relief. Until that time comes, however, the apprenticeship program would

124 See generally, Strauss supra note 89.

125 See note 97 supra and accompanying text.

126 Strauss, supra note 89 , at $302-5$. According to Strauss, apprenticeship replaces only about one-third of the number of union members who leave the union each year.

127 Some authorities list this figure as low as $10 \%$. F. MARshall \& V. Brigcs, supra note 9, at 10; Strauss, supra note 89 , at 316 .

128 Urban League Interview, supra note 23.

129 The following chart, based on federal government statistics, shows the current hourly wage for Chicago area trade unions:

$\begin{array}{lrlr}\text { Asbestos workers } & \$ 6.15 & \text { Ornamental ironworkers } & \$ 6.61 \\ \text { Bricklayers } & 6.55 & \text { - Lathers } & 6.09 \\ \text { Boiler makers } & 6.90 & \text { Painters } & 5.65 \\ \text { Carpenters } & 6.05 & \text { Plasterers } & 6.00 \\ \text { Cement masons } & 5.90 & \text { Pipe fitters } & 6.25 \\ \text { Electricians } & 6.70 & \text { Plumbers } & 6.20 \\ \text { Elevator constructors } & 6.15 & \text { Sprinkler fitters } & 6.29 \\ \text { Glaziers } & 5.77 & \text { Sheetmetal workers } & 6.20 \\ \text { Arch. ironworkers } & 6.61 & \text { Operating eng. } & 4.65-6.05 \\ \text { Structural ironworkers } & 6.85 & & \end{array}$

Structural ironworkers

6.85

6.61

6.09

5.65

6.25

6.29

6.20

Operating eng. $\quad 4.65-6.05$

Frailey, Find Few Blacks in Skill Jobs Here, Chicago Sun-Times, Sept. 6, 1969, at 4. 
seem valid under Title VII because it produces no adverse impact on minority groups..$^{130}$

\section{B. Recruitment Policies}

Two of the most formidable barriers to minority group entry into the building trades are lack of information about job opportunities and fear of rejection by the unions. ${ }^{131}$ Information about job opportunities is, in many instances, disseminated solely through word of mouth, thereby reaching only close friends or relatives of present union members. Since past exclusion has severely limited the number of blacks in trade unions, little information concerning openings or opportunities in the unions filters down to black communities. ${ }^{132}$ Moreover, the news that does reach them is usually negative, consisting of reports of union discrimination. Blacks are thus often reluctant to exploit those union opportunities about which they do hear for fear of being rejected or subjected to hostile union attitudes..$^{133}$

Any union recruitment program which fails to eliminate this lack of information and perceived feeling of hostility will undoubtedly perpetuate the effects of past discrimination. While this fact has been recognized by the courts, ${ }^{134}$ not all of them have forced the union to adopt recruitment policies designed to eliminate such discrimination. For example, the Dobbins court, while recognizing the necessity for affirmative action in this area to eliminate the effects of past discrimination, refused to order the union to seek out individuals in those groups who were competent for referral or membership. ${ }^{135}$ A similar government request for affirmative action was rejected in Local 38, where the court concluded "there is no evidence in the record that the union gave any different information to whites than it did to Negroes."136

The Local 73 and Sheet Metal Workers courts came to a different conclusion. Upon finding that past rejection had led to a lack of information about and feeling of hostility toward the plumbers union

130 The suggested limitations on standards for determining admission to the apprenticeship program should effectively control any union racial bias, so that it would probably be unnecessary for the court to place either apprenticeship admissions or the apprenticeship program itself in the hands of a court appointed trustee (see note 108 supra).

131 F. Marshall \& V. Briggs, supra note 9, at 37-38; Urban League interview, supra note 23.

132 See note 131 supra.

133 Id.

134 See, e.g., United States v. Sheet Metal Workers, Local 36, 416 F.2d 123, 139 (8th Cir. 1969); United States v. Plumbers \& Pipefitters, Local 73, $61 \mathrm{CCH}$ Lab. Cas. I 9329, at 6864 (S.D. Ind. 1969); Dobbins v. IBEW, Local 212, 292 F. Supp. 413, 414-5 (S.D. Ohio 1968).

135292 F. Supp. 413, 445 (S.D. Ohio 1968).

13659 CCH Lab. Cas. I 9226, at 6928 (N.D. Ohio 1969). 
among the black community, the Local 73 court ordered the Joint Apprenticeship Committee (JAC) to take affirmative steps to apprise minority group youth of the qualifications and procedures for admission into the apprenticeship program. These affirmative steps included:

(1) Advertising in at least one local Negro newspaper at least twice within thirty days.

(2) Mailing information circulars to guidance counselors of high schools and junior high schools and to various Negro organizations like the N.A.A.C.P. and the Urban League.

(3) Furnishing the high schools and organizations mentioned above with apprentice application forms.

(4) Requiring a representative of the JAC to contact personally certain predominantly Negro high schools and participate, if permitted to do so, in Career Day-type assemblies and programs designed to acquaint and interest students in the plumbing trade. ${ }^{137}$

The union was ordered to follow all of the above procedures for a two year period (1969-1971).

The court in the Sheet Metal Workers case went even further in placing an affirmative duty of recruitment on the unions. The two locals involved had already taken substantial steps to reduce the effects of past discrimination by sending representatives to make appearances in predominantly black high schools, meeting with area high school counselors on two occasions, running stories in the St. Louis Post Dispatch describing union programs and opportunities, mailing letters to 84 schools, agencies, and organizations, and participating in the Apprenticeship Information Center (A.I.C.) at the Missouri Division of Employment Security. (The A.I.C., in turn, sent qualifications bulletins to Negro organizations like the N.A.A.G.P. and C.O.R.E., issued newspaper, radio, and television releases, and furnished speakers for Career Day programs in high schools). Despite all these measures, the court found union recruitment measures to be inadequate. ${ }^{138}$ It ordered both unions to:

(1) Make school appearances on a more regular basis.

(2) Meet more frequently with high school counselors.

(3) Specifically indicate in its various bulletins, letters, and 
press releases that union programs were open to persons of every race and color. ${ }^{139}$

The strikingly different conclusions reached by the Local 38 and Dobbins courts on the one hand and the Local 73 and Sheet Metal Workers courts on the other may be traced to two sources. The first concerns the good faith the different courts attributed to the respective unions' efforts to end discrimination. The Local 38 and Dobbins courts were impressed with union efforts to eliminate the effects of past discrimination. ${ }^{140}$ Conversely, in the Local 73 case, the court was dubious about the pure intentions behind union efforts, observing that these reform policies were "by no means greeted by the hosannas of all its membership." 141

If the Local 38 and Dobbins courts were convinced that union efforts had completely removed the information gap and had eliminated the effects of past union hostility, then both cases were decided correctly; if no need for affirmative relief exists, none should be granted. If, however, these courts based their decisions upon the good-faith efforts of the union to end these problems rather than upon the actual elimination of those problems, then the merits of the decisions are open to question. As noted above, ${ }^{142}$ subjective intent should have no bearing in deciding when relief is appropriate. Thus, partial improvement will never obviate the need for relief. The correct position seems to be that taken by the Sheet Metal Workers court. Despite the district court's finding that the union had afforded equal treatment to minority groups since the passage of the Civil Rights Act of 1964 and was making determined efforts to recruit black members, the Court of Appeals for the Eighth Circuit concluded that affirmative relief was appropriate, because the recruitment policies of the union still perpetuated the effects of past discrimination. ${ }^{143}$

The second area in which the courts differed concerns the extent of their power to order unions to pursue an affirmative recruitment policy. The difference here reflects the previously discussed division of opinion over whether Congress' desire to end all forms of discrimination or its prohibition on preferential treatment should be given greater emphasis. While the Local 38 and Dobbins courts em-

139 Id. at $139-40$.

140 See notes 39 \& 40 supra. The union in the Dobbins case was even participating in a program (P.R.E.P. Program) with the N.A.A.C.P. and the Cincinnati Urban League designed to help minority group members enter the building trades. $292 \mathrm{~F}$. Supp. 413 , 438 (S.D. Ohio 1968).

14161 CCH Lab. Cas. I 9329, at 6865 (S.D. Ind. 1969).

142 Text at notes $32-48$ supra.

143416 F.2d 123, 138-9 (8th Cir. 1969). 
phasized the latter, ${ }^{144}$ the Sheet Metal Workers and Local 73 emphasized the former. As noted above, ${ }^{145}$ giving greater weight to Congress' desire to end all forms of discrimination represents the sounder interpretation of Title VII; only the granting of relief based solely on evidence of percentage racial imbalance is barred by the Act. The recruitment measures required by the courts in Local 73 and Sheet Metal Workers are not akin to racial quotas. While they would require a wider union dissemination of information in black communities than in white communities, such measures are necessary, in view of both the ignorance about and hostility towards the craft unions in the ghetto, to insure that vital information that is already reaching large segments of the white community is also effectively dispensed to the black community. Thus, the affirmative action ordered in the Sheet Metal Workers and Local 73 cases seems well within the scope of authority Title VII granted the courts for shaping relief.

Under Title VII, the courts have many options available in reshaping union recruitment policies where it finds that (1) information about job opportunities is already available in white communities through informal means and (2) the failure of the unions to provide such information and dispel the perceived feelings of hostility in minority group neighborhoods seriously impedes members of those groups from entering the building trades. Among the steps the courts can require the unions to take are making regular visits to ghetto high schools, meeting with high school guidance counselors, and advertising in media that are likely to reach a minority group audience.

\section{Membership Size}

The ability of the courts to require an increase in union membership size is of crucial importance in any attempt to terminate the present effect of past discrimination by the building trade unions because the present number of membership and apprenticeship openings in any one city at any one time is quite small. ${ }^{146}$ Using Title VII to effect such an increase, however, raises a preemption issue. ${ }^{147}$ Under the Labor-Management Relations Act, ${ }^{148}$ labor unions are not supposed to have the power to control employment in any industry, because it is

\footnotetext{
144 According to the Dobbins court:

In our view affirmative post-Act action, directed toward a group to correct pre-

Act discrimination against that group constitutes the granting of preferential

treatment to that group .... 292 F. Supp. 413, 444 (S.D. Ohio 1968).

145 Text at notes 63-67 supra.

146 F. Marshall \& V. BRIGgs, supra note 9, at 19.

147 Preemption questions may also be raised by Title VII action with respect to admission standards and recruitment policies. To the extent that such questions are present, the following discussion applies.

148 See note 11 supra.
} 
illegal for union membership to be made a precondition for employment. Persons denied employment, because of restrictive union membership policies, therefore, have a remedy before the National Labor Relations Board.

With one rather doubtful exception, ${ }^{149}$ the courts have held that the availability of a remedy under the Labor Acts does not preempt the jurisdiction of the courts over employment practices which also violate Title VII.150 In the two Title VII cases dealing specifically with proposed increases in union membership size, both courts rejected the contention of N.L.R.B. preemption. ${ }^{151}$

The power of the courts to order an increase in union membership size under Title VII has been subject to two views. While the Vogler court sustained its power to increase the size of union membership and order the union to develop objective criteria for determining union size, ${ }^{152}$ the Dobbins court refused to order such relief. ${ }^{163}$ The Dobbins opinion is more a modification of the Vogler ruling than a direct contradiction. The Dobbins court did recognize the appropriateness of relief in the Vogler fact situation-an all white union with a previous record of discrimination limiting either union or apprenticeship membership far below the number necessary for the particular trade..$^{154}$ However, "if the limitation has nothing to do with any discriminatory intention but is related to a reasonable economic purpose, ... Title VII does not require the increase in number even though the union previously (to the Act) discriminated."155 Although the factual situation in Dobbins was similar to that in Vogler, ${ }^{156}$ the court, finding both the absence of an intent to discriminate and a reasonable economic purpose, upheld the union's limitation on membership size. ${ }^{157}$

149 Freese v. John Morrell \& Co., 60 CCH Lab. Cas. I 9231 (S.D. Iowa 1966) upheld the exclusive jurisdiction of the N.L.R.B. over questions that are "arguably" subject to 29 U.S.C. $\$ \S 157$ and 158. Id. at 6505. However, the Court of Appeals for that circuit later came to an opposite conclusion, holding that the Labor acts did not confer exclusive jurisdiction. Norman v. Missouri Pac. R.R., 414 F.2d 73, 82-83 (8th Cir. 1969).

150 See, e.g., Asbestos Workers, Local 53 v. Vogler, 407 F.2d 1047, 1055 (5th Cir. 1969); Norman v. Missouri Pac. R.R., 414 F.2d 73, 82-83 (8th Cir. 1969); Dobbins v. IBEW, Local 212, 292 F. Supp. 413, 446 (S.D. Ohio 1968); Sokolowski v. Swift \& Co., 286 F. Supp. 775, 785 (D. Minn. 1968).

151 Asbestos Workers, Local 53 v. Vogler, 407 F.2d 1047, 1055 (5th Cir. 1969); Dobbins v. IBEW, Local 212, 292 F. Supp. 413, 446 (S.D. Ohio 1968).

152407 F.2d 1047, 1055 (5th Cir. 1969).

163292 F. Supp. 413, 446 (S.D. Ohio 1968).

154 Id.

155 Id.

158 The court found that all of the 800 journeyman members of Local 212 were white, id. at 417; that, because of the shortage of union labor, the union was forced to make a large number of nonunion referrals, id. at 421 ; and that the number of apprentices was fixed at less than half the allowable journeyman-apprentice ratio, id. at 441 .

157 The Dobbins court held that Title VII only required that minority groups be 
In thus limiting to Vogler-type fact situations the judicial power to increase union membership size, the Dobbins court seems to have misconstrued Title VII. Subjective intention and reasonable economic purpose are not valid criteria for evaluating any employment policy. ${ }^{158}$ Limitations on union size should be considered in terms of discriminatory impact, not subjective intent, overriding trade-related purpose, not reasonable economic policy. When considered in these terms, limitations of union and apprenticeship membership below the needs of the industry seem appropriate subjects for judicial relief. Certainly such restrictions are not essential to the efficient functioning of the building industry which is already suffering from a shortage of skilled labor. ${ }^{159}$

The discriminatory impact of these restrictions is also evident. While it is true that restrictions on membership size exclude whites as well as blacks, these policies perpetuate the effects of prior discrimination, achieving almost the same result as outright exclusion by barring significant numbers of blacks from entering the building trades and keeping the craft unions essentially all white. Relief would seem appropriate as long as significant numbers of blacks are denied access to union membership.

The courts have not satisfactorily dealt with the question of what constitutes "a significant number of blacks." While the Vogler court is silent on the subject, the Dobbins court suggests that affirmative relief can be ordered only when the union membership is completely white, a conclusion which would immunize simple tokenism. A better way of defining the term "significant number of blacks" would be to equate it with the percentage of union members who would be black if no discrimination had ever occurred. While it is probably impossible to determine exactly what the racial balance would have been without discrimination, it does not seem unreasonable to set this figure approximately at the percentage of blacks in the population of the geographical jurisdiction of the union involved. Blacks did much of the skilled craft work in the antebellum slave society of the South. There is no reason to think that, if blacks had been allowed equal access to the building trades and given adequate training, they would not

given an equal opportunity to compete for the number of union openings that are available. 292 F. Supp. 413, 446 (S.D. Ohio 1968).

158 See text at notes 32-48 and 66-76 supra.

159 See authorities cited note 2 supra. A major reason that construction prices have risen much more rapidly than the general price index in the past few years is the cost of onsite labor, resulting from the artificial barriers to entry of new workers into the building trades. Sabghin, Kaplan, \& Musgrave, supra note 5, at 5. 
have achieved representation in the craft unions commensurate with their numbers. ${ }^{160}$ The union should therefore be required to maintain its membership size at industry needs as long as the racial composition of this membership departs substantially from the racial composition of the population in the union's jurisdiction.

This standard is not prohibited by section 703(j). The relief is not preferential since, during the time the union would be required to keep its membership size at industry needs, whites would have the same opportunity as blacks to compete for any openings in the apprenticeship program or the union itself. Nor is the relief imposed "on account of" a racial imbalance; it is imposed on account of a pattern or practice of discrimination. The racial imbalance standard is only a temporary measure of the appropriate duration of the relief.

Although the courts have taken the first tentative steps toward establishing in principle their power to force unions to determine the membership size according to industry needs, they have still not decided how to define those industry needs. ${ }^{161}$ While the possible alternatives are undoubtedly endless, some basic observations can be made. Industry needs should not be equated with the number of union members who would be employed on a full-time basis even under the worst foreseeable conditions.

A plan which fixed industry needs at the total number of hours worked in the trade would seem more acceptable. ${ }^{162}$ Under this method, the number of hours worked in the trade by both union and nonunion workers in a particular geographic area during a given year is divided by the number of hours per year which a fully employed union member should expect to work (assuming no overtime). The resulting figure would indicate the level at which membership size should be fixed.

While this plan is objective and more indicative of industry needs than present union methods for determining size, it suffers from two deficiencies. First, the total number of hours worked in the trade may not be truly indicative of the total number of skilled workers who could be employed if available. ${ }^{163}$ Second, any industry estimate relied on to determine the appropriate size of an apprenticeship class must be projected three to five years into the future to allow for the length of the apprenticeship training period. While an ideal estimate of industry needs would take into account the full demand for skilled

160 Strauss \& Ingerman, supra note 22, at 287-9.

101 As of this writing the Vogler court has not accepted any plan.

102 Such a plan has been submitted by the union in the Vogler case. Telephone conversation with an official in the Dept. of Justice, Washington, D.C., Oct. 14, 1969.

163 See authorities cited note 2 supra. 
labor, both present and future, the objectivity and accuracy of such an estimate would be suspect. Forecasting business conditions at some future date is always dependent on "a large element of human judgment,"164 and consequently is subject to a wide margin of error. ${ }^{165}$ This task becomes especially difficult in the construction industry, because of the number of variables involved in determining manpower demand. Not only must general business conditions be considered, but the construction industry must be analyzed in terms of the different types of building which comprise the industry and are influenced by different factors. ${ }^{166}$

Since any estimate of the construction industry demand for skilled labor at a point three to five years in the future would probably be useless as an objective means of determining membership size, it would not seem wise to require judges to choose between equally speculative estimates of competing experts. The plan based upon total hours worked in the trade during a given year seems the more realistic plan for determining both membership and apprenticeship class size.

\section{ConcLusron}

While the courts have begun to take important steps toward using Title VII to eliminate the more complex barriers to minority group entry into the building trades, they have not yet exercised all of the options available to them. Relief is appropriate whenever an intentional union practice or policy ( 1 ) is not essential to the performance of the job involved and (2) has a differential impact on groups excluded in the past. Where both of these factors are present, the court can order the union not only to revise its admission standards and criteria for determining membership size, but also to provide special recruitment services in minority group communities.

\footnotetext{
164 Bureau of Labor Statistics, Rep. No. 248, The forecasting of Manpower REQUIREMENTS 1 (1963).

165 "Last year, for example, many of the business forecasters missed not only the bull's eye but also the target, foreseeing a business slowdown, a lessening of inflation, greater unemployment and less pressure on interest rates. They were wrong on almost all counts." Cunniff, Ups, Downs of Forecasting, Chicago Daily News, Dec. 23, 1969, at 25.

168 D. MCKINLEY, Forecasting Business Condrtions 90 (1965).
} 